\title{
Familial testicular cancer: Interest in genetic testing among high-risk family members
}

June A. Peters, $M S^{1}$, Susan T. Vadaparampil, PhD' ${ }^{2}$, Joan Kramer, $M D^{1}$, Richard P. Moser, PhD ${ }^{3}$, Lori Jo Peterson Court, $M S^{1,4}$, Jennifer Loud, $M S N^{1}$, and Mark H. Greene, $M D^{1}$

\begin{abstract}
Purpose: This study is part of an ongoing National Cancer Institute multidisciplinary, etiologically-focused, crosssectional study of Familial Testicular Cancer (FTC). The current report targets interest in clinical genetic testing for susceptibility to FTC. Methods: Demographics, knowledge, health beliefs, and psychological and social factors were evaluated as covariates related to interest in genetic testing. Results: The majority (66\%) of 229 participants (64 affected men, 66 unaffected men, and 99 women) from 47 multiple-case FTC families expressed interest in having a genetic test within 6 months, should such a test become available. Interest was similar among the three subgroups mentioned above. Worries about insurance discrimination based on genetic test results were associated with a significantly lower interest in testing. Alternatively, participants were more likely to be interested in genetic testing if they were younger and had higher levels of family support, a physician's recommendation supporting testing, cancer distress, and a need for information to inform the health care of their children. Conclusions: This study reveals social and relationship factors that FTC survivors and their relatives considered important when contemplating the use of new genetic technologies. This is the first study describing hypothetical interest in genetic testing for familial testicular cancer. Genet Med 2006:8(12):760-770.
\end{abstract}

Key Words: genetic testing, familial, testicular cancer, social support, psychosocial

Although testicular cancer (TC) accounts for only $1 \%$ of all male cancers, it is the most common cancer in younger men aged 20-35 years old, with about 9,000 new cases occurring annually. ${ }^{1}$ While treatment advances over the last two decades have led to overall survival rates exceeding $85 \%$, there are adverse short-term and long-term treatment effects that may have a lifelong impact on TC survivors' quality of life. ${ }^{2-4} \mathrm{TC}$ incidence rates have been rising since the mid-twentieth century, especially among Caucasian males, ${ }^{5}$ while the rates of many other cancers have been decreasing.

Risk factors for TC include urogenital malformations, testicular dysgenesis, undescended testes, testicular atrophy, history of infertility, prior contralateral TC or testicular intraepithelial neoplasia, and possibly, exposures to a variety of etiologic agents during key developmental periods. ${ }^{6}$ In addition, family history appears to be an important risk factor, with familial clusters of TC representing a well-known, albeit uncommon, occurrence. Approximately $1-3 \%$ of men with testicular cancer report the presence of another affected male in their family. Sons of men with TC

\footnotetext{
${ }^{1}$ Clinical Genetics Branch (CGB), Division of Cancer Epidemiology and Genetics (DCEG), National Cancer Institute (NCI), National Institutes of Health (NIH), DHHS, Rockville, Maryland; ${ }^{2}$ Department of Interdisciplinary Oncology, College of Medicine, University of South Florida, Tampa, Florida; ${ }^{3}$ Division of Cancer Control and Special Populations (DCCPS), NCI, NIH, DHHS, Rockville, Maryland; ${ }^{4}$ Currently at Caldera Pharmaceuticals, Los Alamos, New Mexico. June Peters, CGB, DCEG, NCI, NIH, HHS, 6120 Executive Blvd., EPS 7026, Rockville, MD 20852.E-mail: petersju@mail.nih.gov
}

Submitted for publication March 24, 2006.

Accepted for publication September 19, 2006.

DOI: 10.1097/01.gim.0000250506.15979.0c have a four- to six-fold increased risk of TC, and brothers have an eight- to ten-fold increase in risk when compared with the general population. ${ }^{78}$ Many hereditary disorders or constitutional chromosomal anomalies have been reported in patients who developed seminomatous or nonseminomatous testicular carcinoma. ${ }^{9}$

A clinical phenotype for familial testicular cancer has not yet been established for male and female relatives; therefore, we do not yet know whether any other types of male or female cancers, altered fertility or physical stigmata are associated with inheriting a susceptibility to testicular cancer. One of the purposes of the parent NIH FTC study is to define the clinical phenotype associated with this syndrome. We deliberately chose to study female family members in search of a possible phenotype among women who might be obligate carriers of X-linked Recessive (XLR), Autosomal Dominant (AD) or Autosomal Recessive (AR) gene mutations. Genetic testing could be offered to spouses of affected probands in the future, as the mutation status of spouses might be important for the children of cases and their relatives. Furthermore, spouses are influential in the health care decisions of the family and we thought it appropriate to include them.

It is unclear when a genetic test for determining susceptibility to TC will be developed. FTC susceptibility testing will most likely be a complex undertaking, since the current research suggests that X-linked, autosomal dominant and autosomal recessive genes may all be implicated in the etiology of FTC. Segregation analysis has suggested that no single autosomal gene accounts for all familial risk, and that the genetic basis for FTC may prove to be polygenic. ${ }^{10-14}$ 
When this study was initiated, the International Testicular Cancer Linkage Consortium (ITCLC) had provisionally mapped one putative testicular cancer susceptibility gene (designated TGCT1) to chromosome Xq27. ${ }^{13}$ Six years later, a major FTC susceptibility gene has yet to be identified, despite substantial additional research. ${ }^{15,16}$ The most recent genome-wide linkage analysis reported by the ITCLC did not provide additional support for the hypothesized Xq27 locus, and yielded only modestly interesting LOD scores at other autosomal candidate loci. In this regard, FTC may more closely resemble familial prostate cancer where there is a demonstrated interest in genetic testing, ${ }^{17-20}$ with numerous candidate susceptibility loci having been identified, but to date no major susceptibility genes have been discovered to account for the majority of familial cases. ${ }^{21}$

Thus, it is likely to take longer than anticipated to identify an FTC susceptibility gene and acquire the ability to perform germline mutation testing than it did with Hereditary Breast Ovarian Cancer (HBOC) or Hereditary Non Polyposis Colorectal Cancer (HNPCC). Even if a susceptibility gene were discovered tomorrow, it would probably take six months or more to get a clinical test to market; thus, our question about interest in a hypothetical genetic test was framed in a six-month context.

We wanted to take advantage of the period prior to gene discovery to assess interest in testing, and to ensure appropriate use of genetic testing once it becomes available. ${ }^{22}$ Multiple studies of interest in genetic testing have been conducted in those at risk of a variety of inherited conditions. ${ }^{23-27} \mathrm{We}$ thought it unwise to generalize from these prior studies, which targeted either exclusively female cancer susceptibility syndromes or mixed gender populations (hereditary colon and melanoma syndromes) to our FTC population. Therefore, we felt that we should attempt to determine whether prior findings from earlier studies were applicable to our novel study population.

The development of an accurate genetic test for TC susceptibility would have numerous implications. It would assist individuals in high-risk families in making educated decisions about testing and informing relatives about their risk. It would allow us to better educate men at increased genetic risk regarding proper testicular self-examination procedures, and to offer them more intensive surveillance. Additionally, family members who test negative may have reduced worry about their personal and/or family's risk of developing TC. While the efficacy of these approaches has yet to be established, the possibility of additional intervention based on genetic information provides an important rationale for continued study in this area.

An issue that is often addressed when a new cancer susceptibility syndrome enters active investigation is whether those at risk might be interested in clinical genetic testing. Persons at risk of inherited breast, ovarian, and colorectal cancer syndromes have been studied extensively. ${ }^{23-27}$ Interest rates vary widely across different diseases and populations, as do testing uptake rates and variables associated with interest.

The current study takes advantage of the period prior to FTC gene discovery to assess interest in testing, and to acquire information that may lead to more appropriate use of genetic testing, once it becomes available. ${ }^{22} \mathrm{We}$ present a preliminary analysis of data collected from participants in a multidisciplinary, etiologically focused, cross-sectional study of familial testicular cancer (FTC), currently underway at the U.S. National Cancer Institute. The primary aims of the parent study are identifying FTC susceptibility genes and characterizing the clinical phenotype of the FTC syndrome.

The aims of the current exploratory substudy were 1) identifying whether FTC survivors and their relatives were interested in clinical genetic testing for susceptibility to FTC; and 2) assessing levels of, and specific variables associated with, interest in testing. We designed the substudy using the Health Belief Model (HBM) constructs and terminology. We then chose standardized, validated measures of these variables whenever possible. We based the items on those most commonly cited in the literature and our clinical research experience as factors that may positively or negatively impact interest in genetic testing..$^{28,29,30}$ We also developed several study-specific scales, such as those to measure testicular cancer knowledge and genetics knowledge. Demographics, testicular cancer and genetic knowledge, health beliefs, and psychological and social factors were evaluated as independent variables related to interest in genetic testing.

\section{MATERIALS AND METHODS}

\section{Study population}

The 229 study participants involved in the interest in genetic testing substudy were members of 47 families enrolled on an IRB-approved NCI protocol (\#02-C-0178). Families were eligible if they had two or more confirmed cases of TC, or if they had a single family member with bilateral TC. Eligible individuals included all adult TC survivors and their first-degree relatives (FDRs). The 13 spouses of family members (spouses included in the total $\mathrm{N}$ of 229) were included if they had children at least 12 years of age who were also participating in the study. Any blood relative linking two cases and relatives with cancer other than TC were also eligible. Families have been ascertained through a variety of referral mechanisms: $4 / 47$ (9\%) from the historic NCI- DCEG Human Genetics Program Familial Cancer Registry, ${ }^{31}$ 33/47 (70\%) from various health care providers (e.g. physicians and genetic counselors), primarily in response to mailed recruitment letters; 9/47 (19\%) from a patient advocacy group, the Testicular Cancer Resource Center (TCRC) (http://tcrc.acor.org/); and 1/47 (2\%) self-referred from our FTC Study website (http://familial-testicularcancer.cancer.gov).

\section{Data collection}

Data for this analysis were collected via a mailed, written questionnaire called the Lifestyle and Attitudes Questionnaire (LAQ), which was developed specifically for the larger FTC study. The present analysis was limited to those LAQ items pertaining to interest in genetic testing (GT) and the relevant independent variables. These independent variables include items and scale scores from standardized, validated instru- 
ments, as well as items developed specifically for this study. Three different versions of the LAQ were developed to accommodate our data collection requirements for three specific subsets of participants: 1) LAQMH for affected men with a prior history of TC; 2) LAQMR for unaffected men who are at risk of TC; and 3) LAQF for female family members (spouses, mothers, sisters, and daughters). For example, a man at risk might be asked in the LAQMR about his own risk of developing TC, whereas affected men and female relatives might be asked about the risk faced by the men in their family.

\section{Measures}

For this analysis we chose variables of theoretical and practical interest that are related to the HBM of predicting health behavior, ${ }^{32}$ and other factors, many of which have been shown in previous studies to be related to interest in genetic testing. 33,34

\section{Dependent variable: Interest in genetic testing}

We introduced the topic of genetic testing for TC with the following description: "Among men and women with a strong family history of certain cancers such as colon, breast, and ovarian cancer, genetic testing has become available to identify those at higher risk of developing these specific cancers. If a similar genetic test became available today for testicular cancer susceptibility. ...". Participants were then asked to respond on a five-point Likert scale (from $1=$ strongly agree to $5=$ strongly disagree) to the statement: "I would have the genetic test within the next 6 months." The responses to this interest question were dichotomized and used as the dependent variable of Interest in Genetic Testing by combining "Strongly Agree" and "Agree" to create a "Yes" category, and combining "Don't Know (DK)", "Disagree (D)" and "Strongly Disagree (SD)" to create a "No" category. We assessed the effects of dichotomizing the genetic testing interest variable by comparing "DK" to "D" and "SD" respondents, and found little difference in the distribution of demographic variables (data not shown). Thus, we concluded that there were no statistical barriers to preclude using the dichotomized results.

\section{Independent variables}

The independent variables were grouped into the following categories: Demographic, Knowledge, Health Beliefs, Perceived Benefits and Barriers, Cues to Action, Psychological, and Social factors. We incorporated items based on previous studies of intention to undergo genetic testing for hereditary breast ovarian, colorectal, and prostate cancers. ${ }^{35-38}$ Sample questions for most of the following categories of variables from the Lifestyle and Attitudes Questionnaire are provided in Table 1.

\section{Demographic characteristics}

The following demographic variables were measured: Age (continuous); Gender; Education (High School or less, At least some college, and Graduate training); Have children (Yes, No); Clinical Status (Affected, Unaffected); Ethnicity; and Religion.

\section{Knowledge}

We measured knowledge regarding TC and basic genetic principles with the Testicular Cancer Knowledge Scale (TCKS) and the Genetics Knowledge Scale (GKS) respectively. Each statement in these measures had 3 possible answers of Agree, Disagree, or Don't Know. The TCKS is a 10-item scale (range of scores $=0-10$ determined by the sum of questions answered correctly) based on an instrument developed by Katz and colleagues to assess TC-related knowledge among young adults $($ Cronbach's alpha $=0.70) .{ }^{39}$ It included items regarding TC etiology, the timing and method of testicular self-examination (TSE) and the sequelae of TC.

The GKS was a nine-item scale (range of scores $=0-9$ determined by the sum of questions answered correctly) developed for this study to assess understanding of basic biology and patterns of inheritance (Cronbach's alpha $=0.77$ ), which included general genetics concepts such as chromosomes, genes, and inheritance patterns as well as asking for inferences about the meaning of carrying a mutation, similar to questions used in other hereditary cancer syndromes. ${ }^{40-42}$ However, because of the genetic heterogeneity involved in FTC, the GKS included questions about three different possible inheritance patterns of FTC. For example, a family with two affected brothers (the most common clustering in our study) could represent autosomal dominant $(\mathrm{AD})$, autosomal recessive $(\mathrm{AR})$, X-linked recessive (XLR) or multifactorial inheritance. This complex genetic situation differs from HBOC or HNPCC which show clear autosomal dominant inheritance patterns of inheritance. All of the knowledge scales used in cancer genetic research to date evaluate only $\mathrm{AD}$ inheritance. We wanted to test awareness among participants of all three inheritance patterns.

\section{Health beliefs and attitudes}

We evaluated concepts central to the HBM, including perceived susceptibility and perceived severity of TC, as well as perceived factors that promote or deter interest in genetic testing. ${ }^{43}$ In keeping with the more recent applications of the HBM to a variety of cancer prevention and screening behaviors, ${ }^{44-46}$ we included the "cue to action" construct related to genetic testing. ${ }^{47}$

Perceived susceptibility to testicular cancer scale. Perceived susceptibility was assessed using a previously validated item from health beliefs associated with developing breast cancer ${ }^{48}$ and testicular cancer. ${ }^{49}$ Perceptions of susceptibility to TC were measured by summing the responses to three items on a fivepoint Likert scale $(1=$ strongly agree to $5=$ strongly disagree $)$ (Cronbach's alpha $=0.68)$.

Perceived severity of testicular cancer scale. Perceived severity was assessed using the response to one item on a five-point Likert scale $(1=$ strongly agree to $5=$ strongly disagree $)$ derived from previous research examining health beliefs associated with developing breast cancer ${ }^{48}$ and testicular cancer. ${ }^{49}$ 
Table I

Sample questions from lifestyle and attitudes questionnaire (LAQ)

\begin{tabular}{|c|c|c|}
\hline Variable & Sample question(s) & Possible responses \\
\hline Knowledge of testicular cancer (TCKS) & $\begin{array}{l}\text { Testicular Self Examination (TSE) should be done once } \\
\text { a week (false) }\end{array}$ & $\begin{array}{l}\text { Agree } \\
\text { Disagree } \\
\text { Don't know }\end{array}$ \\
\hline Genetic knowledge (GKS) & $\begin{array}{l}\text { If a person has an altered gene for a disorder, then the } \\
\text { person will definitely get the disorder }\end{array}$ & $\begin{array}{l}\text { Agree } \\
\text { Disagree } \\
\text { Don't know }\end{array}$ \\
\hline Perceived susceptibility to TC & $\begin{array}{l}\text { TC usually develops in people like the men in my } \\
\text { family. It is likely that the men in my family will get } \\
\text { TC. My male family members' chances of getting TC } \\
\text { in the next } 5 \text { years are great }\end{array}$ & $\begin{array}{l}\text { Strongly agree } \\
\text { Agree } \\
\text { Don't know } \\
\text { Disagree } \\
\text { Strongly disagree }\end{array}$ \\
\hline Perceived severity of TC & $\begin{array}{l}\text { If a male family member got TC, its impact on my life } \\
\text { would be severe }\end{array}$ & $\begin{array}{l}\text { Strongly agree } \\
\text { Agree } \\
\text { Don't know } \\
\text { Disagree } \\
\text { Strongly disagree }\end{array}$ \\
\hline $\begin{array}{l}\text { Attitudinal factors promoting interest } \\
\text { in testing }\end{array}$ & $\begin{array}{l}\text { I would have the test if my doctor or other health care } \\
\text { provider recommended it. I would have the test } \\
\text { ONLY if I knew that the test result would help me } \\
\text { make choices about my health care. I would have the } \\
\text { test if the test result would be useful in making } \\
\text { choices about the health care of my children }\end{array}$ & $\begin{array}{l}\text { Strongly agree } \\
\text { Agree } \\
\text { Don't know } \\
\text { Disagree } \\
\text { Strongly disagree }\end{array}$ \\
\hline $\begin{array}{l}\text { Attitudinal factors deterring interest in } \\
\text { genetic testing }\end{array}$ & $\begin{array}{l}\text { I would not have the test because I am concerned that } \\
\text { this information could interfere with my getting a } \\
\text { job. I would not have the test because I am } \\
\text { concerned that this information could interfere with } \\
\text { my getting insurance. I would not have the test } \\
\text { because it is too painful. I would not have the test } \\
\text { because it might cost too much }\end{array}$ & $\begin{array}{l}\text { Strongly Agree } \\
\text { Agree } \\
\text { Don't know } \\
\text { Disagree } \\
\text { Strongly disagree }\end{array}$ \\
\hline
\end{tabular}

Perceived benefits of genetic testing. We developed two items to assess positive attitudes toward genetic testing for TC on a five-point Likert Scale $(1=$ strongly agree to $5=$ strongly disagree), should such a test become available. Examples are included in Appendix 1. Given the different dimension of interest that each item represents, and noting that scores on these items were not highly correlated, we chose to independently examine the association of each factor with interest in testing, rather than using an overall perceived benefits scale.

Perceived barriers. We developed four items on a five-point Likert scale $(1=$ strongly disagree to $5=$ strongly agree $)$ to assess the participants' negative attitudes toward such a test, again representing a mixture of social and health concerns. These items were analyzed separately.

Cue to action for genetic testing. Previous studies of genetic testing for hereditary cancer that have found physician recommendation to be a key factor in predicting both interest in and uptake of genetic testing. ${ }^{36,50,51}$ Therefore, we developed a single item to assess the perceived importance of physician recommendation on interest in genetic testing for TC on a fivepoint Likert Scale $(1=$ strongly agree to $5=$ strongly disagree $)$, should such a genetic test become available.

\section{Psychological variables}

We measured the psychological characteristics cancer worry, cancer distress (intrusive thoughts) and avoidance, and overall distress (global severity of symptoms).

Cancer worry. We used a modified Lerman Cancer Worry Scale to assess cancer worry among men at risk of TC. ${ }^{28}$ The Breast Cancer Worry scale is a scale that assesses frequency of concerns about developing breast cancer and the impact of cancer worry on mood and daily functioning. It has high internal consistency (Cronbach's alpha $=0.86)$ and is widely-utilized. ${ }^{52-54}$ Higher worry scores have been associated with inappropriate adherence to mammography screening ${ }^{55}$ and breast self-examination ${ }^{56}$ in at-risk women. For this study we modified the breast cancer scale to a four-point $(1=$ not at all or rarely to $4=$ a lot $)$ TC worry cancer scale targeting concerns, thoughts and feelings about TC, and their effects on daily functioning, with the wording adjusted appropriately for unaffected and affected men and female family members.

Distress via the impact of events scale (IES). The IES ${ }^{8}$ measures the subjective impact of a specific event on an individual by assessing two major responses to stressful events: intrusion and avoidance. In this self-administered scale, respondents are asked to indicate using a four-point response scale $(0=$ not at 
all, $1=$ rarely, $3=$ sometimes, $5=$ often), how frequently with respect to TC a set of 15 statements about TC risk occurred during the past 7 days. Intrusion is characterized by repetitive thoughts, mental images, disturbing dreams, and repetitive behavior. Avoidance is associated with denial of consequences from an event, blunting feelings, and emotional numbness related to an event. ${ }^{55,57}$ The IES allows for the calculation of an overall score ranging from $0-75$, an intrusion subscale score ranging from $0-35$, and an avoidance subscale score ranging from $0-40$. The IES has been found to be a reliable and valid instrument for cancer-related distress among men and women either affected by or at risk of a variety of cancers. ${ }^{58}$

Brief Symptom Inventory 18. The Brief Symptom Inventory 18 (BSI-18) is a standardized, validated 18-question instrument that assesses the respondent's overall levels of current psychological distress via a summary Global Severity Index (GSI). Three subscales of 6 questions each pertaining to symptoms of somatization, depression, and anxiety are summed to compute the GSI (Cronbach's alpha $=0.89) .{ }^{59}$

\section{Social variables}

The measures of social and economic variables assessed in the present study included self-reported social support, insurance status and concern for the well-being of children (among those with children).

Social support. Previous studies emphasize the important role of the family in genetic testing decisions. ${ }^{30,60}$ We used the standardized Duke Social Support and Stress Scale (DUSOCS) ${ }^{61}$ to measure levels of family and non-family stress and social support. It is brief, practical in a clinical setting, and focuses primarily on the quality rather than the quantity of support in 4 domains: family support, non-family support, family stress and non-family stress. Each domain is comprised of the sum of 9 four-point Likert questions (with $1=$ none, $2=$ some; $3=$ a lot; $4=$ no such person, range $=7-21$ ), with published Cronbach's alpha coefficients ranging from 0.53 to 0.70 .

"Having a child," "For my Children," and their interaction. We hypothesized that there might be an interaction relative to interest in genetic testing between the demographic variable of having at least one child, and agreeing with the Health Benefit item "I would have the genetic test if I knew that the test result would be useful in making choices about the health care of my children." Each of these variables as well as the interaction term were included as variables in the analyses.

Insurance status. Participants were asked whether they currently had health, disability or life insurance coverage (yes, no).

\section{Data analysis}

The main outcome of interest was Interest in Genetic Testing, a dichotomous variable consisting of those who expressed an interest in genetic testing for TC susceptibility versus those who did not.
Initial analyses were performed using a standard statistical software package (SPSS, version 12), and subsequent multivariate logistic regressions with SAS version 9.1.3. All $P$-values were two-sided.

First, a univariate analysis was performed to distinguish those interested versus those participants not interested in genetic testing, based on demographic characteristics, knowledge, health beliefs, psychological and social factors. Independent variables that were significant at $P<0.10$ ( $t$-test, ANOVA, $\chi^{2}$ test) were then simultaneously entered into a multiple logistic regression model.

Before entering the significant variables into a final model, we performed bivariate correlations between all the variables to test for multi-colinearity. None of the correlations were strong enough to warrant exclusion of any of the variables from the final model. The final analytic step consisted of creating a parsimonious model which included only the significant $(P<0.05)$ independent variables from the multiple logistic regression model.

Although the individual was the unit of analysis in this study, the familial nature of the cohort raised concerns regarding the assumption of independence of observations. Therefore, all logistic models were conducted with a program that accounted for possible clustering within families (SAS Proc Surveylogistic; SAS Institute, 2003). The procedure uses the Taylor expansion method to estimate sampling errors of estimators based on potential clustering of responses between family members. We performed subgroup analyses in several instances when it seemed appropriate (e.g. results for males only, or when we obtained unexpectedly high correlations) in order to better explain the results obtained from our analyses.

\section{RESULTS}

\section{Response rates and respondent characteristics}

The response rate for adult participants completing the Lifestyle and Attitudes Questionnaire (LAQ) was 90\%. Table 2 summarizes the demographic characteristics of the study population.

This study population consisted of 229 men and women, with most participants being Non-Hispanic, Caucasian, middle-aged, well-educated, and married with children. Our sample included 99 female (43\%) and 130 (57\%) male participants between ages $19-87$ years old (mean age $=48 \pm 17$ ), including 64 men with a prior history of TC and 66 unaffected men at risk. Thirteen of the 99 women were spouses of affected men or spouses of first-degree relatives. We were committed to including the women based on the reasons related to the scientific aims of the overall study as explained above, due to their possible involvement in transmission of genetic susceptibility and because of their social roles as agents of health promotion within their families. In order to assess whether spouses might differ from blood relatives, we ran the statistical analyses both with and without them. We found that the results did not differ based on whether or not the spouses were included; therefore, we included them in the results presented below. Three-quar- 
Table 2

Demographic and other characteristics of participants

\begin{tabular}{|c|c|c|}
\hline Characteristic & $\mathrm{N}$ & $\%$ \\
\hline Number of individuals & 229 & - \\
\hline Number of families & 47 & - \\
\hline \multicolumn{3}{|l|}{ Age by decade (yr) } \\
\hline$<20$ & 2 & 1 \\
\hline $20-29$ & 28 & 12 \\
\hline $30-39$ & 37 & 16 \\
\hline $40-49$ & 59 & 26 \\
\hline $50-59$ & 46 & 20 \\
\hline$\geq 60$ & 57 & 25 \\
\hline Gender male & 130 & 57 \\
\hline \multicolumn{3}{|l|}{ LAQ version } \\
\hline Affected males & 64 & 28 \\
\hline Unaffected males at risk & 66 & 29 \\
\hline Female relatives and spouses & 99 & 43 \\
\hline Married & 154 & 67 \\
\hline \multicolumn{3}{|l|}{ Education } \\
\hline$\leq \mathrm{HS}$ & 49 & 21 \\
\hline$\geq$ College & 117 & 51 \\
\hline Graduate level and above & 65 & 28 \\
\hline Race (Caucasian/white) & 229 & 99 \\
\hline Health insurance coverage & 219 & 95 \\
\hline Life insurance coverage & 174 & 75 \\
\hline Disability insurance coverage & 103 & 45 \\
\hline \multicolumn{3}{|l|}{ Relationship to case } \\
\hline Case & 64 & 28 \\
\hline First-degree relative & 119 & 52 \\
\hline Second-degree relative & 31 & 13 \\
\hline Spouse & 10 & 4 \\
\hline Number of families with $\geq 2$ cases in family & 34 & 72 \\
\hline Number of families with bilateral cases & 13 & 28 \\
\hline
\end{tabular}

Percentages may not add to $100 \%$ due to missing values and unknown information.

ters of participants reported being either Catholic $(40 \%)$ or Protestant (36\%), 10\% named no religious affiliation, $5 \%$ were Mormon, and the remainder reported various other religions. Eighty-seven percent of the families had 2 or more confirmed cases of TC, including 5 sets of twins, while $13 \%$ of the families had 1 confirmed bilateral TC case.

\section{Interest in genetic testing}

Of the 229 participants who completed the LAQ, 220 (95\%) responded to the statement "I would have the genetic test within 6 months." When this variable was dichotomized, about two thirds (66\%) agreed or strongly agreed that they would obtain genetic testing for TC within 6 months, if it were to become available.

\section{Individual factors associated with interest in genetic testing}

The factors associated with interest in genetic testing in the univariate analyses are listed in Table 3 , along with the significance levels of the differences in means between those interested in testing versus those with no interest. When univariate analyses were conducted, we found that those interested in genetic testing were likely to have attitudes about genetic testing that corresponded to their endorsing more of the items that promote interest and less that deter. Individual factors positively correlated with interest in genetic testing at $P<0.05$ were younger age at the time of completing the LAQ, physician recommendation to be tested, testing for the health of one's children, higher cancer worry and distress and higher family social support. Respondents who said that they would not have the genetic test because of concerns about health and job dis-

\section{Table 3}

Covariates associated with interest/non-interest in genetic testing using univariate analyses on $\mathrm{N}=220$

\begin{tabular}{|c|c|c|c|}
\hline Interest score (range) & $\begin{array}{l}\text { Test interest } \\
\text { group }\end{array}$ & $\operatorname{Mean}(\mathrm{SD})^{a}$ & $\begin{array}{c}T \text {-test } \\
p \text {-value }\end{array}$ \\
\hline $\begin{array}{l}\text { If my physician recommended } \\
(1-5)\end{array}$ & $\begin{array}{l}\text { No interest/DK } \\
\text { Interested }\end{array}$ & $\begin{array}{l}2.1(1.1) \\
1.4(0.7)\end{array}$ & 0.000 \\
\hline $\begin{array}{l}\text { ONLY for own healthcare } \\
(1-5)\end{array}$ & $\begin{array}{l}\text { No interest/DK } \\
\text { Interested }\end{array}$ & $\begin{array}{l}2.5(1.2) \\
3.2(1.2)\end{array}$ & 0.000 \\
\hline $\begin{array}{l}\text { For health of my children } \\
\quad(1-5)\end{array}$ & $\begin{array}{l}\text { No interest/DK } \\
\text { Interested }\end{array}$ & $\begin{array}{l}1.7(0.9) \\
1.3(0.6)\end{array}$ & 0.000 \\
\hline $\begin{array}{l}\text { No test if concern about } \\
\text { health insurance }(1-5)\end{array}$ & $\begin{array}{l}\text { No Interest/DK } \\
\text { Interested }\end{array}$ & $\begin{array}{l}3.6(1.0) \\
4.2(0.9)\end{array}$ & 0.000 \\
\hline Cancer worry (4-16) & $\begin{array}{l}\text { No interest/DK } \\
\text { Interested }\end{array}$ & $\begin{array}{l}5.7(1.8) \\
6.8(2.4)\end{array}$ & 0.001 \\
\hline $\begin{array}{l}\text { No test if concern about job } \\
\text { discrimination (1-5) }\end{array}$ & $\begin{array}{l}\text { No interest/DK } \\
\text { Interested }\end{array}$ & $\begin{array}{l}4.2(0.8) \\
4.5(0.7)\end{array}$ & 0.006 \\
\hline $\begin{array}{l}\text { Family social support } \\
\text { (DUSOCS) }(0-1)\end{array}$ & $\begin{array}{l}\text { No interest/DK } \\
\text { Interested }\end{array}$ & $\begin{array}{l}0.4(0.1) \\
0.5(0.2)\end{array}$ & 0.006 \\
\hline Age (19-87) & $\begin{array}{l}\text { No interest/DK } \\
\text { Interested }\end{array}$ & $\begin{array}{l}52.2(16.7) \\
46.0(15.6)\end{array}$ & 0.009 \\
\hline $\begin{array}{l}\text { No test if concern about } \\
\text { pain }(1-5)\end{array}$ & $\begin{array}{l}\text { No interest/DK } \\
\text { Interested }\end{array}$ & $\begin{array}{l}3.6(1.0) \\
4.0(1.0)\end{array}$ & 0.010 \\
\hline Cancer distress (7-21) & $\begin{array}{l}\text { No interest/DK } \\
\text { Interested }\end{array}$ & $\begin{array}{r}8.5(3.6) \\
10.0(4.1)\end{array}$ & 0.015 \\
\hline $\begin{array}{l}\text { No test if concern about } \\
\text { cost }(1-5)\end{array}$ & $\begin{array}{l}\text { No interest/DK } \\
\text { Interested }\end{array}$ & $\begin{array}{l}3.4(1.0) \\
3.7(1.1)\end{array}$ & 0.015 \\
\hline $\begin{array}{l}\text { No test if concern about lack } \\
\text { of prevention (MEN only) } \\
(1-5)\end{array}$ & $\begin{array}{l}\text { No interest/DK } \\
\text { Interested }\end{array}$ & $\begin{array}{l}3.9(0.8) \\
4.2(0.8)\end{array}$ & 0.034 \\
\hline Susceptibility to TC $(0-10)$ & $\begin{array}{l}\text { No interest/DK } \\
\text { Interested }\end{array}$ & $\begin{array}{l}8.7(1.9) \\
9.3(2.0)\end{array}$ & $0.055^{b}$ \\
\hline $\begin{array}{l}\text { TC knowledge scale } \\
(0-10)\end{array}$ & $\begin{array}{l}\text { No interest/DK } \\
\text { Interested }\end{array}$ & $\begin{array}{l}4.5(2.5) \\
5.1(2.3)\end{array}$ & $0.069^{b}$ \\
\hline
\end{tabular}


crimination, pain, and cost were less likely to agree with an interest in genetic testing. Men who agreed with the statement "I would not have the genetic test because there may not be treatments that will prevent me from getting testicular cancer" were less likely to agree with an interest in genetic testing.

Perceived TC Susceptibility $(P=0.55)$ and TC Knowledge $(P=0.69)$ were marginally significant measures associated with interest in testing. Those who were most likely to indicate an interest in testing were least likely to endorse the statement that they would test ONLY for their own health care $(P<$ $0.000)$. Factors not significantly associated with interest in genetic testing $(P<0.10)$ were gender, education, disease affected status, health insurance status, TC knowledge, genetic knowledge, perceived TC susceptibility, and global distress.

We ran the multiple logistic regression analyses with the variables above that were significant in the univariate analyses in two ways: first without adjusting for familial clustering, and finally with Proc Survey Logistic Regression, to adjust for familial clustering. The results were similar. The more conservative Proc Survey Logistic results are presented in Table 4 summarizing the seven variables that remained significantly associated with interest in genetic testing.

The variable most strongly associated with interest in GT was family social support $(\mathrm{OR}=78.4 ; \mathrm{CI}=8.9-688.2)$. The interaction between having a child and interest in testing for the health of the children was significant $(\mathrm{OR}=4.1$; $\mathrm{CI}=$ 1.7-9.5, $P<0.01, F=10.5$ ). People with children who agreed with the statement that they would test "for the sake of the children's health" were 3 times more likely to be interested in genetic testing than not interested. This relationship was significant only for those who had at least one child.

Other significant variables associated with higher test interest were greater endorsement of physician recommendation $(\mathrm{OR}=2.5 ; \mathrm{CI}=1.4-4.5)$ and cancer distress $(\mathrm{OR}=1.2 ; \mathrm{CI}=$ $1.0-1.3)$ as well as slightly younger age. Those least concerned about insurance status were more likely to be interested in genetic testing (OR 2.0; CI = 1.4-2.4). Those most likely to say that they would test ONLY for their own health care were least likely to be interested in genetic testing ( $\mathrm{OR} 1.5 ; \mathrm{CI}=1.0-2.1)$.

\section{DISCUSSION}

This analysis represents the first data related to interest in genetic testing for susceptibility to familial testicular cancer. It included both men (either cancer survivors or their at-risk male relatives) and women (their female relatives and spouses) from high-risk families. The majority (66\%) of our FTC study participants expressed an interest in having a genetic test for susceptibility to familial testicular cancer, within 6 months of such a test becoming available. In the final multivariate analysis, the independent variables that remained statistically associated with interest in testing were family social support, the interaction between having a child and wanting testing for the sake of children's health care, physician recommendation to undergo testing, cancer distress, and younger age. Those who were less likely to be interested in testing more often endorsed concern about health insurance discrimination, and interest ONLY for one's own health care.

Social support, as measured by the family support subscale of the DUSOCS, showed a highly significant $(\mathrm{OR}=78.4$; $\mathrm{CI}=$ 8.9-688.2) relationship with interest in genetic testing. While the confidence interval is wide, this is the strongest association that we observed. We noticed that a large percentage (90\%) of people with a high family social support score were interested in genetic testing. Conversely, very few people with high amounts of social support were not interested, resulting in a very small cell size for this latter subset of participants.

Our observation about social support and genetic testing being related (not necessarily causal) is consistent with other studies. ${ }^{34}$ Prior studies have found that lower social support at the time of testing may be associated with greater risk of both short- and long-term emotional distress. ${ }^{62,63}$ To the extent that a decision regarding genetic testing is a difficult and stressful event, the active involvement of a highly supportive family may facilitate making such a choice. Therefore, it may be worthwhile to develop novel and efficient tools to better assess different domains of social support of those undergoing genetic testing, and to actively encourage cultivation of other sources of support (e.g. friends, coworkers, members of one's religious community) when the family is found to be unavailable for

Table 4

Covariates associated with interest/non-interest in genetic testing in multivariate logistic regression analyses (adjusted for family clustering on $\mathrm{N}=220$ )

\begin{tabular}{|c|c|c|c|}
\hline Independent variable & $\begin{array}{c}\text { Multivariate logistic regression } \\
\text { odds ratio }\end{array}$ & $95 \%$ CI & $P$-values \\
\hline Family social support (DUSCOS) & 78.4 & $8.9-688.2$ & $<0.01$ \\
\hline Interaction of having children ${ }^{\star}$ For the health of my children & 4.1 & $1.7-9.5$ & $<0.01($ Wald $\mathrm{F}=10.51)$ \\
\hline If my physician recommended & 2.5 & $1.4-4.5$ & $<0.01$ \\
\hline Not interested in test due to concern re: insurance discrimination & 2.0 & $1.4-2.4$ & $<0.01$ \\
\hline Not interested in test ONLY for own healthcare & 1.5 & $1.0-2.1$ & $<0.04$ \\
\hline Distress (intrusion) & 1.2 & $1.0-1.3$ & $<0.01$ \\
\hline Age & 0.96 & $0.93-0.99$ & $<0.03$ \\
\hline
\end{tabular}


support. Efforts along these lines are being pursued in families with Hereditary Breast/Ovarian Cancer. ${ }^{64}$

We found that respondents with children were three times as likely to be interested in testing, and were more likely to endorse the statement that they were interested in testing for the sake of their children's health. Those most interested tended to disagree with the statement that they would have a genetic test ONLY for their own health care. These findings are consistent with previous studies which have found that providing information that can be used for health care decision-making by family members, particularly children, is one of the most important independent variables associated with interest in and/or intention to obtain genetic testing for a variety of hereditary cancers. ${ }^{65-68}$ These findings make sense in that our study participants recognize that genetic medicine is family medicine.

In our study, knowledge of testicular cancer as measured by the TCKS and knowledge of genetics principles as measured by the GKS were not statistically associated with interest in genetic testing. Perhaps knowledge is necessary but not sufficient to make informed choices about genetic testing, and that personal values and feelings are more influential. We anticipated that the levels of genetic and medical knowledge of participants would generally be low, and have, therefore, been providing a standardized TC and genetic education module following completion of the questionnaire to our study participants who attend clinic, as a routine part of our clinical protocol (manuscript in preparation).

In the current study, physician recommendation supporting the value of genetic testing was an important variable associated with FTC testing interest $(\mathrm{OR}=2.5 ; 95 \% \mathrm{CI}=1.4-4.5)$. Physician recommendation has consistently been shown to influence people's attitudes toward, and decisions about, various medical interventions for members of cancer-prone families, including genetic testing, tamoxifen chemoprevention, prostate cancer screening, and mammography utilization after receiving a $B R C A 1$ negative result. ${ }^{51,69-72}$ High-risk patients' reliance upon physician recommendation in guiding their health care decision-making is particularly noteworthy given recent trends away from an authoritarian relationship between physician and patient, toward a partnership model of health care. It underscores how critically important it is for physicians to have the knowledge and skill set required to provide authoritative, accurate and family-centered genetic information to their high-risk patients, who face very difficult and complicated decisions. ${ }^{18,73-75}$ Much of this genetic information has evolved over the past decade, and is unfamiliar even to physicians whose specialty interests regularly bring them into contact with patients in need of this advice. ${ }^{76}$ This speaks to a need for continuing education for non-genetics health care providers, and for active collaborations and referrals between providers and genetics professionals.

Our results support observations made in other cancer susceptibility disorders that cancer distress or worry are prevalent in women and men seeking cancer genetic counseling, and that they are positively associated with interest in, and uptake of, genetic education, counseling and testing 19,67,77-79. Effective genetic counseling has been shown in some cases to reduce cancer worry as well as unrealistic risk perception and test expectations ${ }^{80-82}$ Consequently, cancer genetic counseling for TC should also address the issue of cancer distress prior to attempting a decision regarding testing.

Fear of genetic discrimination remains a social barrier to genetic testing. While the vast majority of study participants (95\%) currently had health insurance, those who expressed greater concern that participation in genetic testing for FTC might affect their insurance status reported less interest in genetic testing. ( $\mathrm{OR}=2.0 ; 95 \% \mathrm{CI}=1.4-2.4)$ This is consistent with similar fears expressed by participants in studies on genetic testing for hereditary pancreatitis, Alzheimer disease, prostate cancer and colon cancer. ${ }^{66,67,83,84}$ In the absence of a comprehensive, nationwide legal prohibition against genetic discrimination in health insurance underwriting, and coupled with mistrust of existing laws ${ }^{85}$ perhaps due to warnings regarding the potential for such discrimination that have become part of standard pretest informed consent process (despite the lack of evidence suggesting that this is really a major problem $^{86}$ ), it is hardly surprising that these concerns should comprise a deterrent to cancer susceptibility mutation testing.

While the results of this first study of interest in genetic testing for familial TC provide important insight into factors that may influence subsequent uptake in testing if such a test were to become available, there are also certain limitations that should be considered. Our findings may not be generalizeable to members of all families with TC, in that our data comprise a cross-sectional assessment of individuals and families who volunteered to participate in a gene discovery study that required them to travel from home to the NIH Clinical Center for a two-day research evaluation. However, the diversity of referral sources (urologists, oncologists, genetic counselors, self-referral from the study website, patient advocacy group and others) and recruitment of families from throughout the U.S. are study strengths.

It is clear that reported test interest does not reflect actual uptake of genetic testing. Our purpose was not to predict actual uptake of genetic testing but rather to characterize a novel population of families with multiple testicular cancers. Other studies of interest in genetic testing obtained interest ranging from $20 \%$ to $95 \%$ among women at risk of breast cancer while actual test uptake and returning for disclosure were considerably less. ${ }^{17,23,30,87-92} \mathrm{~A}$ recent systematic review of uptake rates for breast cancer genetic testing found a mean hypothetical uptake of $66 \%$ and mean actual uptake of 59\%. ${ }^{93}$ Stated interest has also been high with lower actual uptake for colon cancer, Huntington's disease, Alzheimer's disease and alcoholism. ${ }^{26,94-97}$ There are many potential reasons why interest does not always translate into testing, including many of the barriers that we identified such as cost, pain, inconvenience and fear of insurance discrimination or social stigma. Additionally, there may be unrealistic expectations among those seeking testing as typified in a study by Press et al. in which study participants were most interested in a test that didn't exist (one with a high pos- 
itive predictive value (PPV) followed by an effective noninvasive preventive therapy), and least interested in the test that does exist (less than certain PPV, low negative predictive value, and limited invasive, objectionable therapeutic options). ${ }^{38}$ These authors concluded that careful counseling would be needed to prevent health care providers from recommending a test to patients that will subsequently disappoint them. We consider examination of the interest in genetic testing as an evidence-based approach to understanding the beliefs, knowledge, feelings, attitudes and social context of this under-studied population, rather than to assume that they will seek genetic testing at the same rates as they indicated their interest.

Further research is needed once susceptibility genes have been identified to show whether increased genetic information such as susceptibility test results will lead to improved medical management of members of FTC families. We will have to await the discovery of more definitive genetic etiologic data to answer this question. During the interim, this study enhances the literature on interest in genetic testing by focusing on relevant psychological and social factors which TC survivors and their families considered important when contemplating the use of new genetic technologies.

\section{ACKNOWLEDGMENTS}

This research was supported by the Intramural Research Program of the National Institutes of Health, by the National Cancer Institute, Division of Cancer Epidemiology and Genetics, Clinical Genetics Branch.

We would like to thank all of the staff from the Clinical Genetics Branch of the National Cancer Institute and Westat, Inc. for their expertise and valued contributions to the NCI FTC protocol, specifically for their assistance with study development and management as well as data collection, coding and analysis. Larissa Korde, Sharon Savage, Deliya Ryan and Jose Reyes were especially helpful in the latter stages of data analysis and manuscript revision. Our special thanks to all of the participants in the NCI FTC study.

\section{References}

1. Edwards BK, Brown ML, Wingo PA, Howe HL, et al. Annual Report to the Nation on the Status of Cancer, 1975-2002, Featuring Population-Based Trends in Cancer Treatment. JNCI Cancer Spectrum 2005;97:1407-1427.

2. Al Tourah AJ, Murray N, Coppin C, Kollmannsberger C, et al. Minimizing treatment without compromising cure with primary surveillance for clinical stage I embryonal predominant nonseminomatous testicular cancer: A population based analysis from British Columbia. Urology 2005;174:2209-2213.

3. Bloom JR, Fobair P, Gritz E, Wellisch D, et al. Psychosocial outcomes of cancer: A comparative analysis of Hodgkin's disease and testicular cancer. J Clin Oncol 1993; 11:979-988.

4. Sirohi B, Huddart R. The management of poor-prognosis, non-seminomatous germ-cell tumours. Clinical Oncology 2005;17:543-552.

5. Purdue MP, Devesa SS, Sigurdson AJ, McGlynn KA, et al. International patterns and trends in testis cancer incidence. Int J Cancer 2005;115:822-827.

6. Kramer JL, Greene MH. Hereditary Testicular Cancer. In: Vogelzang N, Scardino P, Shipley W, Debruyne F, Linehan WM, editors. Comprehensive Textbook of Genitoruinary Oncology. 3rd ed. Philadelphia: Lippincott; 2006, pp 558-562.

7. Dieckmann K, Pichlmeier U. The prevalence of familial testicular cancer: an anlysis of two patient populations and a review of the literature. Cancer 1997;80:1954-1960.

8. Hemminki K, Li XJ, Czene K. Familial risk of cancer: Data for clinical counseling and cancer genetics. International Journal of Cancer 2004;108:109-114.
9. Holzik ML, Rapley EA, Hoekstra HJ, Sleijfer DT, et al. Genetic predisposition to testicular germ-cell tumours. The Lancet Oncology 2004;5:363-371.

10. Bishop DT, Rapley E, Crockford G, Biggs P, et al. Candidate regions for testicular cancer susceptibility genes: The results of two genomic searches. Am J Hum Genet 1997;61:A268.

11. Heimdal K, Olsson H, Tretli S, Fossa SD, et al. A segregation analysis of testicular cancer based on Norwegian and Swedish families. Brit J Cancer 1997;75:1084-1087.

12. Rapley E, Tucker K, Collins F, Donald J, et al. Candidate regions for testicular cancer susceptibility genes. APMIS 1998;106:64-70.

13. Rapley EA, Crockford GP, Teare D, Biggs P, et al. Localization to Xq27 of a susceptibility gene for testicular germ-cell tumours. Nat Genet 2000;24:197-200.

14. Rapley EA, Crockford GP, Easton DF, Stratton MR, et al. Localisation of susceptibility genes for familial testicular germ cell tumour. APMIS 2003;111:128-135.

15. Nathanson KL, Kanetsky PA, Hawes R, Vaughn DJ, et al. The Y deletion gr/gr and susceptibility to testicular germ cell tumor. Am J Hum Genet 2005;77:1034-1043.

16. Crockford GP, Linger R, Hockley S, Dudakia D, et al. Genome-wide linkage screen for testicular germ cell tumour susceptibility loci. Human Molecular Genetics 2006; 15:443-451.

17. Bratt $\mathrm{O}$, Kristoffersson U, Lundgren $\mathrm{R}$, Olsson $\mathrm{H}$, et al. Sons of men with prostate cancer: Their attitudes regarding possible inheritance of prostate cancer, screening, and genetic testing. Urology 1997;50:360-365.

18. Bratt O, Damber J-E, Emanuelsson M, Kristoffersson U, et al. Risk perception, screening practice and interest in genetic testing among unaffected men in families with hereditary prostate cancer. Eur J Cancer 2000;36:235-241.

19. Diefenbach MA, Schnoll RA, Miller SM, Brower L, et al. Genetic testing for prostate cancer - Willingness and predictors of interest. Cancer Practice 2000;8:82-86.

20. Doukas DF, Fetters MD, Coyne JC, McCullough LB, et al. How men view genetic testing for prostate cancer risk: findings from focus groups. Clin Genet 2000;58:169-176.

21. Xu JF, Dimitrov L, Chang BL, Adams TS, et al. A combined genomewide linkage scan of 1,233 families for prostate cancer-susceptibility genes conducted by the international consortium for prostate cancer genetics. Am J Hum Genet 2005;77: 219-229.

22. Burke W, Zimmern RL. Science and society - Ensuring the appropriate use of genetic tests. Nat Rev Genet 2004;5:955-959.

23. Struewing JP, Lerman C, Kase RG, Giambarresi TR, et al. Anticipated uptake and impact of genetic testing in hereditary breast and ovarian cancer families. Cancer Epidemiol Biomarkers Prev 1995;4:169-731.

24. Andrykowski MA, Lightner R, Studts JL, Munn RK, et al. Hereditary cancer risk notification and testing: how interested is the general population? J Clin Oncol 1997; 15:2139-2148.

25. Vernon SW, Gritz ER, Peterson SK, Perz CA, et al. Intention to learn results of genetic testing for hereditary colon cancer. Cancer Epidemiol Biomarkers Prev 1999; 8:353-360.

26. Gamm JL, Nussbaum RL, Biesecker BB. Genetics and alcoholism among at-risk relatives II: Interest and concerns about hypothetical genetic testing for alcoholism risk. Am J Med Genet 2004;128:A151-A155.

27. Sanderson SC, Wardle J, Jarvis MJ, Humphries SE, et al. Public interest in genetic testing for susceptibility to heart disease and cancer: a population-based survey in the UK. Prevent Med 2004;39:458-464.

28. Lerman C, Daly M, Masny A, Balshem A, et al. Attitudes about genetic testing for breast-ovarian cancer susceptibility. J Clin Oncol 1994;12:843-850.

29. Hughes C, Gomez-Caminero A, Benkendorf J, Kerner J, et al. Ethnic differences in knowledge and attitudes about BRCAl testing in women at increased risk. Patient Educ Couns 1997 September;32:51-62.

30. Biesecker BB, Ishibe N, Hadley DW, Giambarresi TR, et al. Psychosocial factors predicting BRCA1/BRCA2 testing decisions in members of hereditary breast and ovarian cancer families. Am J Med Genet 2000;93:257-263.

31. Greene MH. Cancer families: A resource for etiologic studies. In: Castellani A, editor. Epidemiology and Quantitation of Environmental Risks in Humans from Radiation and Other Agents- Potential and Limitations. New York: Plenum Press; 1985: pp 213-223.

32. Rosenstock IM, Strecher VJ, Becker MH. Social learning theory and the health belief model. Health Education Quarterly 1988;15:175-183.

33. Armstrong K, Weiner J, Weber B, Asch DA. Early adoption of BRCA1/2 testing: Who and why. Genet Med 2003;5:92-98.

34. Bowen DJ, Bourcier E, Press N, Lewis FM, et al. Effects of individual and family functioning on interest in genetic testing. Community Genetics 2004;7:25-32.

35. Kinney AY, Croyle RT, Bain C, Pelias MZ, et al. Knowledge, attitudes, and interest in breast-ovarian cancer gene testing: A survey of a large African-American kindred with a BRCA1 mutation. J Law Medicine \& Ethics 2001;29:47-48.

36. Vadaparampil ST, Azzarello L, Pickard J, Jacobsen PB. Intention to obtain genetic testing for melanoma among first degree relatives of melanoma patients. Am J Hematol 2006. 
37. Kinney AY, Choi YA, DeVellis B, Kobetz E, et al. Interest in genetic testing among first-degree relatives of colorectal cancer patients. Am J Prevent Med 2000;18:249252

38. Press NA, Yasui Y, Reynolds S, Durfy SJ, et al. Women's interest in genetic testing for breast cancer susceptibility may be based on unrealistic expectations. Am J Med Genet 2001;99:99-110.

39. Katz RC, Meyers K, Walls J. Cancer awareness and self-examination practices in young men and women. J Behav Med 1995;18:377-384.

40. Biesecker BB, McInerney A, Fost N, Green M, et al. Outcomes of a randomised trial on the use of a CD-ROM program on breast cancer genetics: Client knowledge, preferences and intent to undergo BRCA1/2 testing. J Med Genet 2000;37:6.

41. Glanz K, Grove J, Lerman C, Gotay C, et al. Correlates of intentions to obtain genetic counseling and colorectal cancer gene testing among at-risk relatives from three ethnic groups. Cancer Epidemiol Biomarkers Prev 1999;8:329-336.

42. Bluman LG, Rimer BK, Berry DA, Borstelmann N, et al. Attitudes, knowledge, and risk perceptions of women with breast and/or ovarian cancer considering testing for BRCA1 and BRCA2. J Clin Oncol 1999;17:1040-1046,

43. Rosenstock IM. Why people use health services. Milbank Mem Fund Q 1966;44 (Suppl):127.

44. Earp JA, Eng E, O’Malley MS, Altpeter M, et al. Increasing Use of Mammography Among Older, Rural African American Women: Results From a Community Trial. Am J Pub Health 2002;92:646-654

45. Goldring AB, Taylor SE, Kemeny ME, Anton PA, et al. Impact of Health Beliefs, Quality of Life, and the Physician-Patient Relationship on the Treatment Intentions of Inflammatory Bowel Disease Patients. [Article]. Health Psychol 2002 May;21:219-228.

46. Hay JL, Ford JS, Klein D, Primavera LH, et al. Adherence to colorectal cancer screening in mammography-adherent older women. Health Psychol 2003;21:553-576.

47. Janz NK, Champion VL, Strecher VJ. The health belief model. In: Glanz K, Rimer BK, Lewis FM, editors. Health behavior and health education: Theory, research, and practice, $3^{\text {rd }}$ ed. San Francisco: Jossey-Bass, 2002;45-66.

48. Champion VL, Scott CR. Reliability and validity of breast cancer screening belief scales in African American women. Nurs Res 1997;46:331-337.

49. Blesch KS. Health beliefs about testicular cancer and self-examination among professional men. Oncologist 1986;13:29-33.

50. Kinney AY, Croyle RT, Dudley WN, Bailey CA, et al. Knowledge, attitudes, and interest in breast-ovarian cancer gene testing: A survey of a large African-American kindred with a BRCA1 mutation. Prevent Med 2001;33:543-551.

51. Schwartz MD, Lerman C, Brogan B, Peshkin BN, et al. Utilization of BRCA1/BRCA2 mutation testing in newly diagnosed breast cancer patients. Cancer Epidemiol Biomarkers \& Prevention 2005; 14:1003-1007.

52. Audrain J, Schwartz MD, Lerman C, Hughes C, et al. Psychological distress in women seeking genetic counseling for breast-ovarian cancer risk: the contributions of personality and appraisal. Ann Behav Med 1998;19:370-377.

53. Friedman LC, Webb JA, Richards CS, Plon SE, et al. Psychological and behavioral factors associated with colorectal cancer screening among Ashkenazim. Prev Med 1999;29:119-125.

54. Lerman C, Schwartz MD, Lin TH, Hughes C, et al. The influence of psychological distress on use of genetic testing for cancer risk. J Consult Clin Psychol 1997;65:414420

55. Lerman C, Rimer B, Trock B, Balshem A, et al. Factors associated with repeat adherence to breast cancer screening. Prev Med 1990;19:279-290.

56. Brain K, Norman P, Gray J, Rogers C, et al. A randomized trial of specialist genetic assessment: psychological impact on women at different levels of familial breast cancer risk. Brit J Cancer 2002;86:233-238.

57. Horowitz M, Wilner N, Alvarez W. Impact of Event Scale: A measure of subjective stress. Psychom Med 1979;41:209-218.

58. Vadaparampil ST, Ropka M, Stefanek ME. Measurement of psychological factors associated with genetic testing for hereditary breast, ovarian and colon cancers. Familial Cancer 2005;4:195-206.

59. Derogatis L. Brief Symptom Inventory 18 (BSI 18) administration, scoring, and procedures manual. Minneapolis: National Computer Systems; 2001.

60. Peterson SK, Watts BG, Koehly LM, Vernon SW, et al. How families communicate about HNPCC genetic testing: Findings from a qualitative study. Am J Med Genet 2003 May 15;119:C78-C86.

61. Parkerson GR, Boradhead WE, Tse CK. Validation of the Duke Social Support and Stress Scale. Fam Med 1991;23:357-360.

62. Gritz ER, Peterson SK, Vernon SW, Marani SK, et al. Psychological impact of genetic testing for hereditary nonpolyposis colorectal cancer. J Clin Oncol 2005;23:19021910.

63. Manne S, Audrain J, Schwartz M, Main D, et al. Associations between relationship support and psychological reactions of participants and partners to BRCAl and BRCA2 testing in a clinic-based sample. Ann Behav Med 2004;28:211-225.

64. Peters JA, Kenen R, Giusti R, Loud J, et al. Exploratory study of the feasibility and utility of the colored eco-genetic relationship map (CEGRM) in women at high genetic risk of developing breast cancer. Am J Med Genet Part A 2004;130:A258A264.

65. Lerman C, Schwartz MD, Miller SM, Daly M, et al. A randomized trial of breast cancer risk counseling: interacting effects of counseling, educational level, and coping style. Health Psychol 1996;15:75-83.

66. Applebaum-Shapiro SE, Peters JA, O'Connell JA, Aston CE, et al. Motivations and concerns of patients with access to genetic testing for hereditary pancreatitis. Amer Gastroenterol 2001;96:1610-1617.

67. Hadley DW, Jenkins J, Dimond E, Nakahara K, et al. Genetic counseling and testing in families with hereditary nonpolyposis colorectal cancer. Arch Intern Med 2003 163:573-582.

68. Bratt OKU, Lunetta KL, Olsson H. Sons of men with prostate cancer: Their attitudes regarding possible inheritance of prostate cancer, screening, and genetic testing. Adult Urology 1997;50:360-365.

69. Bober SL, Hoke LA, Duda RB, Regan MM, et al. Decision-making about tamoxifen in women at high risk for breast cancer: Clinical and psychological factors. J Clin Oncol 2004;22:4951-4957.

70. Kim HL, Benson DA, Stern SD, Gerber GS, et al. Practice trends in the managemen of prostate disease by family practice physicians and general internists: An Internetbased survey. Urology 2002;59:266-271.

71. Plon SE, Peterson LE, Friedman LC, Richards CS, et al. Mammography behavio after receiving a negative BRCA1 mutation test result in the Ashkenazim: A com munity-based study. Genet Med 2000;2:307-311.

72. Pickles T. What's a man to do? Treatment options for localized prostate cancer. Can Fam Phys 2004;50:65-72.

73. Boulware LE, Meoni LA, Fink NE, Parekh RS, et al. Preferences, knowledge, com munication and patient-physician discussion of living kidney transplantation in African American families. Am J Transplant 2005;5 (6):1503-12.

74. Braun KL, Fong M, Kaanoi ME, Kamaka ML, et al. Testing a culturally appropriate, theory-based intervention to improve colorectal cancer screening among Native Hawaiians. Prevent Med 2005;40:619-627.

75. Scheuner MT, Yoon PW, Khoury MJ. Contribution of mendelian disorders to com mon chronic disease: Opportunities for recognition, intervention, and prevention. Am J Med Genet Part C-Seminars in Medical Genetics 2004;125:C50-C65.

76. Wideroff L, Vadaparampil ST, Greene MH, Taplin S, et al. Hereditary breast/ovarian and colorectal cancer genetics knowledge in a national sample of US physicians. Med Genet 2005;42:749-755.

77. Audrain J, Schwartz MD, Lerman C, Hughes C, et al. Psychological distress in women seeking genetic counseling for breast- ovarian cancer risk: the contributions of personality and appraisal. Ann Behav Med 1998;19:370-377.

78. Gwyn K, Vernon SW, Conoley PM. Intention to pursue genetic testing for breas cancer among women due for screening mammography. Cancer Epidemiol Biomar kers Prev 2003;12:96-102.

79. Vernon SW, Gritz ER, Peterson SK, Perz CA, et al. Intention to learn results of genetic testing for hereditary colon cancer. Cancer Epidemiol Biomarkers Prev 1999; $8: 353-360$

80. Bowen DJ, Burke W, McTiernan A, Yasui Y, et al. Breast cancer risk counseling improves women's functioning. Patient Educ Couns 2004;53 (1):79-86.

81. Durfy SJ, Bowen DJ, McTiernan A, Sporleder J, et al. Attitudes and interest in genetic testing for breast and ovarian cancer susceptibility in diverse groups of women in western Washington. Cancer Epidemiol Biomarkers Prev 1999;8:369-375.

82. Foster C, Evans DGR, Eeles R, Eccles D, et al. Non-uptake of predictive genetic testing for BRCA1/2 among relatives of known carriers: Attributes, cancer worry, and barriers to testing in a multicenter clinical cohort. Genet Test 2004;8 (1):23-9.

83. Cutler SJ, Hodgson LG. To test or not to test: interest in Genet Test for Alzheimer's disease among middle-aged adults. American Journal of Alzheimer's Disease and Other Dementias 2003;18:9-20.

84. Doukas DJ. Genetics providers and the family covenant: Connecting individuals with their families. Genet Test 2003;7:315-321.

85. Hall MA, Rich SS. Patients' fear of genetic discrimination by health insurers: the impact of legal protections. Genet Med 2000;2:214-221.

86. Greely HT. Banning genetic discrimination. N Engl J Med 2005;353:865-867.

87. Bottorff JL, Ratner PA, Balneaves LG, Richardson CG, et al. Women's interest in Genet Test for breast cancer risk: The influence of sociodemographics and knowledge. Cancer Epidemiol Biomarkers Prev 2002;11:89-95.

88. Kash KM, Dabney MR. Psychological aspects of cancer screening in high-risk populations. Med Pediatr Oncol 2001;36:519-524.

89. Lerman C, Narod S, Schulman K, Hughes C, et al. BRCA1 testing in families with hereditary breast-ovarian cancer. A prospective study of patient decision making and outcomes [see comments]. JAMA 1996;275:1885-1892.

90. Lerman C, Seay J, Balshem A, Audrain J, et al. Interest in Genet Test among firstdegree relatives of breast cancer patients. Am J Med Genet 1995;57:385-392.

91. Lipkus IM, Iden D, Terrenoire J, Feaganes JR, et al. Relationships among Breast Cancer Concern, Risk Perceptions, and Interest in Genet Test for Breast Cance 


\section{Peters et al.}

Susceptibility among African-American Women with and without a Family History of Breast Cancer. Cancer Epidemiol Biomarkers Prev 1999;8:533-539.

92. Meijers-Heijboer H, Brekelmans CTM, Menke-Pluymers M, Seynaeve C, et al. Use of Genet Test and prophylactic mastectomy and oophorectomy in women with breast or ovarian cancer from families with a BRCA1 or BRCA2 mutation. J Clin Oncol 2003;21:1675-1681.

93. Ropka ME, Wenzel J, Phillips EK, Siadaty M, et al. Uptake Rates for Breast Cancer Genet Test: A Systematic Review. Cancer Epidemiol Biomarkers Prev 2006;15:840 855
94. Craufurd D, Dodge A, Kerzin-Storrar L, Harris R, et al. Uptake of presymptomatic predictive testing for Huntington's disease. Lancet 1989;2:603-605.

95. Lerman C, Hughes C, Trock BJ, Myers RE, et al. Genet Test in families with hereditary nonpolyposis colon cancer. JAMA 1999;281:1618-1622.

96. Quaid KA, Morris M. Reluctance to Undergo Predictive Testing - the Case of Huntington Disease. Am J Med Genet 1993;45:41-45.

97. Roberts JS, Barber M, Brown TM, Cupples LA, et al. Who seeks genetic susceptibility testing for Alzheimer's disease? Findings from a multisite, randomized clinical trial. Genet Med 2004;6:197-203. 